\title{
PENAMBAHAN SENAM OTAK PADA PROGRAM SENAM SEHAT ANAK INDONESIA (SSAI) DAPAT MENINGKATKAN MEMORI JANGKA PENDEK DAN INDEKS KESEGARAN JASMANI SISWA SD INPRES PONDANG
}

\author{
Joanne Ingrid Robot ${ }^{1}$, I Nyoman Adiputra ${ }^{2}$, S. Indra Lesmana ${ }^{3}$, I Dewa Putu Sutjana ${ }^{4}$, I Putu \\ Adiartha Griadhi ${ }^{5}$, M. Ali Imron ${ }^{6}$ \\ ${ }^{1}$ Program Studi Magister Fisiologi Keolahragaan Universitas Udayana Denpasar Bali \\ ${ }^{2,4,5}$ Fakultas Kedokteran Universitas Udayana Denpasar Bali \\ ${ }^{3}$ Fakultas Fisioterapi Universitas Esa Unggul Jakarta \\ ${ }^{6}$ Program Studi Fisioterapi Stikes Aisyiyah Yogyakarta
}

\begin{abstract}
ABSTRAK
Latar Belakang: Memori jangka pendek mempunyai pengaruh dalam setiap tahapan proses kognitif yang terjadi pada individu anak. Proses stimulasi memori jangka pendek akan mempengaruhi kecepatan proses kognitif. Stimulasi yang diberikan berupa gerakan-gerakan yang mengaktifkan otak membuat memori jangka pendek akan lebih terintegrasi dengan memori jangka panjang untuk memperkaya muatan yang sudah ada dalam memori jangka panjang. Fungsi kognitif dan prestasi akademik juga dipengaruhi oleh tingkat kesegaran jasmani. Kapasitas fisik anak sangat dipengaruhi oleh kesegaran jasmani untuk menunjang meningkatnya prestasi anak. Tujuan: Untuk membuktikan bahwa penambahan senam otak pada SSAI dapat meningkatkan memori jangka pendek dan indeks kesegaran jasmani siswa SD Inpres Pondang. Metode: Penelitian ini menggunakan metode true eksperimental, dengan rancangan two group pre and post test control group design. Kelompok perlakuan dan kelompok kontrol diberikan pelatihan 3 kali seminggu sebanyak 6 minggu. Sampel dalam penelitian ini berjumlah 42 orang yang terbagi dalam dua kelompok. Kelompok kontrol diberikan SSAI dan kelompok perlakuan diberikan penambahan senam otak pada program SSAI. Alat ukur dalam penelitian ini menggunakan memory span untuk mengukur memori jangka pendek dan TKJI untuk mengukur kesegaran jasmani. Hasil Penelitian: Hasil pengujian hipotesis menggunakan Wilcoxon test dan Mann Whitney test. Hasil dari Wilcoxon test menunjukkan peningkatan memori jangka pendek pada kelompok perlakuan secara signifikan $(\mathrm{p}<0,05)$, kelompok kontrol menunjukkan peningkatan memori jangka pendek secara signifikan $(\mathrm{p}<0,05)$. Hasil uji hipotesis menunjukkan nilai peningkatan indeks kesegaran jasmani pada kelompok perlakuan secara signifikan $(\mathrm{p}<0,05)$. Nilai peningkatan indeks kesegaran jasmani pada kelompok kontrol secara signifikan $(\mathrm{p}<0,05)$. Hasil uji Mann Whitney test menunjukkan nilai digit span pada kelompok perlakuan dan kelompok kontrol dengan nilai $p=0,005(p<0,05)$. Nilai kesegaran jasmani pada kelompok perlakuan dan kelompok kontrol dengan nilai $p=0,091$ ( $p>0,05)$. Simpulan: Secara statistik ada beda penambahan senam otak pada SSAI dalam meningkatkan memori jangka pendek siswa SD. Secara statistik tidak ada beda penambahan senam otak pada SSAI dalam meningkatkan kesegaran jasmani pada siswa SD.
\end{abstract}

Kata Kunci : Memori jangka pendek, indeks kesegaran jasmani, memory span, tes kesegaran jasmani Indonesia, senam otak, senam sehat anak Indonesia. 


\title{
ADDITION OF BRAIN GYM IN THE PROGRAM OF SENAM SEHAT ANAK INDONESIA (SSAI) CAN INCREASE SHORT-TERM MEMORY AND PHYSICAL FITNESS INDEX IN ELEMENTARY SCHOOL STUDENTS OF INPRES PONDANG
}

\begin{abstract}
Background: Short-term memory plays a role in all children's cognitive processes both in understanding the language, working on the task and problem-solving process. The speed of cognitive processes in children depend on the degree of activation of short-term memory. With stimulation that given in the form of brain-activating movements is expected to integrate short-term memory and long-term memory to generate new knowledge or expand the existing load in longterm memory. Cognitive function and academic achievement can also be influenced by the level of physical fitness. Physical fitness is very useful to support the physical capacity of children who in the end expected to improve his performance. Objective: This research was conducted to find out how big increase of short-term memory and physical fitness at the addition of Brain Gym in SSAI program at elementary school student of Inpres Pondang. Method: This research is true experimental, using two group pre and post test control group design. This research was conducted at SD Inpres Pondang, 3 times weekly for 6 weeks, at January 22, 2018 - March 05, 2018. The sample of research is 42 people divided into two groups. The Control Group in the form of SSAI program and the Treatment Group was given the addition of Brain Gym in the SSAI program. The measuring instrument used to memory span to measure short-term memory and TKJI to measure physical fitness. Results: The results of hypothesis testing using Wilcoxon test and Mann Whitney test. Wilcoxon test results showed short-term memory improvement in the treatment group significantly $(\mathrm{p}<0.05)$, the control group showed significant short-term memory increase $(\mathrm{p}<0.05)$. The result of hypothesis test shows the value of increase of physical fitness index in the treatment group significantly $(\mathrm{p}<0.05)$. The increase value of physical fitness index in control group significantly $(\mathrm{p}<0.05)$. Mann Whitney test results showed the value of span digits in the treatment group and control group with $\mathrm{p}=0.005(\mathrm{p}<0.05)$. Physical fitness value in treatment group and control group with $\mathrm{p}$ value $=0.091(\mathrm{p}>0.05)$. Conclusion: Statistically there is a difference in the addition of brain gymnastics to SSAI in increasing short-term memory of elementary students. Statistically there is no difference in the addition of brain gymnastics in SSAI in improving physical fitness in elementary school students.
\end{abstract}

Keywords: Short term memory, physical fitness, memory span, Indonesian physical fitness test, brain gym, healthy gymnastics Indonesian children.

\section{PENDAHULUAN}

Proses stimulasi memori jangka pendek akan berpengaruh pada tahapan perkembangan kognitif dari seorang anak. Peneliti dalam bidang neuroscientist menemukan bahwa perkembangan kognitif anak berkaitan erat dengan perkembangan dan fungsi otak. Perkembangan kognitif termasuk dalam proses genetik yang didasarkan pada perkembangan sistem saraf. Menurut teori yang dikemukakan oleh Piaget, proses tumbuh kembang pada anak akan melewati tahapan yang sama, akan tetapi proses tersebut bisa terjadi dengan kecepatan yang berbeda. Perkembangan kognitif, dalam hal ini proses penalaran tidak bisa diajar secara langsung, tetapi bisa distimulasi. ${ }^{1}$

Memori termasuk bagian penting dalam proses perkembangan kognitif, karena setiap tahapan proses belajar dari suatu individu anak akan melibatkan memori. Banyak siswa yang mengalami hambatan ketika belajar di karenakan proses di otak seperti di paksa untuk bekerja sehingga memicu terjadinya mekanisme stres. Proses integrasi pada otak menjadi berkurang sehingga beberapa bagian 
pada otak tertentu menjadi kurang berfungsi. Mekanisme stres ini bisa mempengaruhi proses pengolahan informasi yang masuk di otak sehingga pelajar merasa tidak mampu untuk mencerna informasi atau sulit untuk berkonsentrasi. Pelajar yang mengalami stres masuk dalam keadaan homolateral, di mana isi otak dominan mengerjakan kebanyakan proses mental sedangkan belahan otak yang tidak dominan kurang dapat diakses. Pelajar tidak bisa menunjukkan potensi yang dimilikinya karena fungsi otak tidak seimbang sehingga pelajar akan sulit berkonsentrasi pada pelajaran sehingga informasi terbaru akan sulit dicerna dan dimengerti. ${ }^{2}$ Memori jangka pendek harus diperkuat dan ditingkatkan agar ketika suatu informasi masuk di otak, ada sistem memori yang akan menyimpan informasi tersebut dan meneruskannya ke memori jangka panjang untuk diproses dan disimpan ke area otak yang lebih berperan untuk membuat informasi menjadi permanen. Dengan stimulasi yang diberikan berupa gerakan-gerakan yang mengaktifkan otak diharapkan memori jangka pendek akan lebih terintegrasi dengan memori jangka panjang untuk menghasilkan pengetahuan baru atau mengubah dan memperkaya muatan yang sudah ada dalam memori jangka panjang.

Proses interaksi yang terjadi antara faktor lingkungan, faktor sosial dan genetik sangat mempengaruhi tahapan perkembangan intelektual pada individu. Selain itu, tingkat kesegaran jasmani bisa mempengaruhi fungsi intelektual dan prestasi di bidang akademik. Kesegaran jasmani yang baik pada anak mempunyai peran untuk meningkatkan kapasitas fisik anak, sehingga anak bisa berprestasi.

Dengan kesegaran jasmani yang baik, diharapkan seorang anak akan mampu mengikuti kegiatan belajar mengajar di sekolah dengan efektif, daya tahan tubuh meningkat, serta dapat berprestasi. ${ }^{3}$

Umur anak yang terlibat dalam penelitian ini adalah $10-12$ tahun. Karena rentang usia 10 - 12 tahun pada anak adalah usia yang potensial untuk di stimulasi memori jangka pendekny. Karena diketahui, memori jangka pendek pada usia 10 hingga 12 tahun, dapat mengalami peningkatan sampai 5 digit. Perkembangan anak-anak di usai 10 sampai 12 tahun berada dalam tahapan memulai kesiapan menghadapi tugas-tugas yang diberikan sehingga membutuhkan penampilan kebugaran fisik yang baik dan konsentrasi yang baik pada pelajaran. ${ }^{4}$

Senam adalah serangkaian aktivitas jasmani yang terbukti sangat efektif dalam proses tumbuh kembang anak. Jenis senam yang bisa diberikan adalah Senam Sehat Anak Indonesia dan Senam Otak. ${ }^{5}$

Senam Otak adalah serangkaian gerakangerakan yang sederhana yang bisa menstimulasi fungsi otak manusia. Karena dalam senam ini terdiri dari gerakan yang melibatkan aktivitas fisik, beberapa fungsi organ bisa menjadi lebih baik karena adanya perbaikan dalam metabolisme tubuh dan adanya peningkatan energi tubuh. ${ }^{6}$

SSAI merupakan salah satu jenis senam kesegaran jasmani yang aktivitasnya tidak hanya menggunakan fisik semata tetapi menuntut koordinasi gerak tubuh. Unsurunsur gerakan kesegaran jasmani adalah kekuatan, kecepatan, ketepatan, daya tahan, kecepatan, kelincahan, koordinasi kelentukan, dan keseimbangan. ${ }^{7}$

Penelitian ini bertujuan untuk membuktikan penambahan senam otak pada SSAI dapat meningkatkan memori jangka pendek dan indeks kesegaran jasmani siswa SD Inpres Pondang.

Hipotesis penelitian ini adalah (1) Penambahan senam otak pada SSAI dapat meningkatkan memori jangka pendek siswa SD Inpres Pondang. (2) Penambahan senam otak pada SSAI dapat meningkatkan indeks kesegaran jasmani siswa SD Inpres Pondang.

\section{METODE PENELITIAN}

\section{A. Rancangan Penelitian}

Rancangan penelitian ini adalah eksperimental, menggunakan metode randomized pre-test and post-test control group design. Desain penelitian ini membandingkan Kelompok Perlakuan dan Kelompok Kontrol. Kelompok Perlakuan dengan penambahan senam otak pada SSAI dan Kelompok Kontrol dengan SSAI. 


\section{B. Tempat dan Waktu Penelitian}

Penelitian ini bertempat di SD Inpres Pondang, Kecamatan Amurang Timur, Kabupaten Minahasa Selatan. Waktu penelitian dimulai dengan persiapan penelitian (Januari 2018) sampai penyusunan laporan (Juni 2018).

\section{Populasi dan Sampel}

Yang termasuk populasi target adalah siswa usia $10-12$ tahun di SD Inpres Pondang. Dan populasi terjangkau adalah anak usia 10-12 tahun yang bisa mengikuti program yang dilakukan oleh peneliti dan memenuhi kriteria inklusi dan eksklusi. Sampel yang diambil dari populasi secara acak dengan rumus Pocock untuk menentukan besaran sampel. ${ }^{8}$

Teknik pengambilan sampel adalah menentukan SD Inpres Pondang yang akan dijadikan tempat asal sampel. Mengumpulkan sampel siswa usia 10-12 tahun yang ada di kelas 4-6 SD. Total jumlah siswa sebagai populasi terjangkau adalah 78 orang, yang kemudian diseleksi berdasarkan kriteria inklusi dan eksklusi. Didapatkan 42 orang siswa yang memenuhi syarat kriteria inklusi dan eksklusi. Pembagian kelompok menjadi dua kelompok, di mana masing-masing kelompok berjumlah 21 orang, dan untuk pembagian kelompok di lakukan dengan cara random alokasi memakai teknik undian.

\section{Prosedur Penelitian}

Setelah subjek menandatangani informed consent, kemudian masuk pada tahap pelaksanaan. Tahap pelaksanaan: (a) Menetapkan Kelompok Perlakuan dan Kelompok Kontrol berdasarkan kriteria inklusi dan eksklusi. (b) Melakukan pengukuran memori jangka pendek dan indeks kesegaran jasmani. (c) Kelompok Perlakuan menerima perlakuan penambahan senam otak pada SSAI dan Kelompok Kontrol menerima perlakuan SSAI dengan frekuensi 3 kali seminggu selama 6 minggu. (d) Melakukan pengukuran memori jangka pendek dan indeks kesegaran jasmani.

\section{E. Analisis Data}

Analisis data untuk pengujian statistik pada penelitian ini adalah uji hipotesis I dan II menggunakan Wilcoxon test dan uji hipotesis III menggunakan Mann Whitney test.

\section{HASIL PENELITIAN}

\section{Deskripsi Karakteristik Subjek Penelitian}

Tabel 1

Karakteristik Sampel

\begin{tabular}{lll}
\hline \multirow{2}{*}{\begin{tabular}{c} 
Karakteristik \\
\multicolumn{1}{c}{ Sampel }
\end{tabular}} & $\begin{array}{l}\text { Kelompok } \\
\text { Perlakuan }\end{array}$ & $\begin{array}{l}\text { Kelompok } \\
\text { Kontrol }\end{array}$ \\
\cline { 2 - 3 } & Rerata \pm SB & Rerata \pm SB \\
\hline $\begin{array}{l}\text { Umur (th) } \\
\text { Tinggi Badan } \\
(\mathrm{cm})\end{array}$ & $11,10 \pm 0,62$ & $11,33 \pm 0,73$ \\
$\begin{array}{l}\text { Berat Badan } \\
(\mathrm{kg})\end{array}$ & $36,38 \pm 2.72$ & $37,52 \pm 5,45$ \\
$\mathrm{IMT}\left(\mathrm{kg} / \mathrm{m}^{2}\right)$ & $17,83 \pm 2,56$ & $17,78 \pm 1,49$ \\
\hline
\end{tabular}

Tabel 2

Deskriptif Data Sampel Berdasarkan Jenis Kelamin

\begin{tabular}{ccccc}
\hline Sampel & \multicolumn{2}{c}{$\begin{array}{c}\text { Kelompok } \\
\text { Jenis } \\
\text { Perlakuan }\end{array}$} & \multicolumn{3}{c}{$\begin{array}{c}\text { Kelompok } \\
\text { Kontrol }\end{array}$} \\
\cline { 2 - 5 } Kelamin & $\mathrm{N}$ & $\%$ & $\mathrm{~N}$ & $\%$ \\
\hline Laki-laki & 12 & 57,1 & 11 & 52,4 \\
Perempuan & 9 & 42,9 & 10 & 47,6 \\
\hline
\end{tabular}

Distribusi sampel berdasarkan jenis kelamin menunjukkan bahwa laki-laki sebanyak $57,1 \%$ dan perempuan $42,9 \%$ pada Kelompok Perlakuan. Pada Kelompok Kontrol memperlihatkan bahwa 52,4\% lakilaki dan perempuan sebanyak $47,6 \%$.

\section{Uji Normalitas Data}

Tabel 3

Uji Normalitas Data

\begin{tabular}{llcc}
\hline \multirow{2}{*}{ DIGIT SPAN \& TKJI } & \multicolumn{2}{c}{ Uji Normalitas } \\
\cline { 3 - 4 } & & \multicolumn{1}{c}{$\mathrm{KP}$} & $\mathrm{KK}$ \\
\cline { 2 - 4 } & nilai $\mathrm{p}$ & nilai $\mathrm{p}$ \\
\hline Memori Jangka Pendek & Pre & 0,013 & 0,008 \\
& Post & 0,001 & 0,006 \\
Kesegaran Jasmani & Pre & 0,005 & 0,002 \\
& Post & 0,001 & 0,000 \\
\hline
\end{tabular}

Tabel di atas menggambarkan bahwa pada uji normalitas (shapiro wilk test) semua 
nilai $\mathrm{p}<0,05$, sehingga bisa ditarik kesimpulkan bahwa data-data tersebut berdistribusi tidak normal sehingga menggunakan uji beda nonparametrik.

\section{Uji Beda Nilai Digit Span dan Indeks Kesegaran Jasmani Sebelum dan Sesudah Perlakuan pada Kedua Kelompok}

Tabel 4

Nilai Digit Span

\begin{tabular}{cccc}
\hline \multirow{2}{*}{$\begin{array}{c}\text { Varia } \\
\text { bel }\end{array}$} & Sebelum & Sesudah & $\begin{array}{c}\text { Nilai } \\
\mathrm{p}^{*}\end{array}$ \\
\cline { 2 - 4 } & Rerata \pm SB & Rerata \pm SB & \\
\hline \multirow{3}{*}{ KP } & $8,43 \pm 1,39$ & $11,90 \pm 0,99$ & 0,001 \\
KK & $8,43 \pm 1,43$ & $10,81 \pm 1,07$ & 0,001 \\
\hline p $^{* *}$ & 0,990 & 0,005 & \\
\hline
\end{tabular}

Keterangan:

$\mathrm{p}^{*}$ : Hasil uji beda menggunakan Wilcoxon test

$\mathrm{p}^{* *}$ : Hasil uji beda menggunakan Mann Whitney test

Berdasarkan tabel di atas hasil uji Wilcoxon test menunjukkan nilai $\mathrm{p}$ pada ke dua kelompok lebih kecil dari 0,05 yang mempunyai arti bahwa terdapat perbedaan nilai memori jangka pendek yang bermakna sebelum dan sesudah perlakuan penambahan senam otak pada SSAI dan pemberian SSAI. Terjadi peningkatan memori jangka pendek sebesar 70,84\% pada Kelompok Perlakuan, dan 77,98\% pada Kelompok Kontrol.

Hasil uji Mann Whitney test setelah perlakuan pada Kelompok Perlakuan yang diberikan penambahan Senam Otak pada SSAI dan Kelompok Kontrol SSAI menunjukkan nilai $\mathrm{p}$ kurang dari 0,05 berarti terdapat perbedaan peningkatan memori jangka pendek yang bermakna sebelum dan setelah perlakuan SSAI dan penambahan senam otak pada SSAI.

Tabel 5

Nilai Indeks Kesegaran Jasmani

\begin{tabular}{cccc}
\hline \multirow{2}{*}{$\begin{array}{c}\text { Varia } \\
\text { bel }\end{array}$} & Sebelum & Sesudah & $\begin{array}{l}\text { Nilai } \\
\mathrm{p}^{*}\end{array}$ \\
\cline { 2 - 4 } & Rerata \pm SB & Rerata \pm SB & \\
\hline \multirow{3}{*}{ KP } & $13,62 \pm 1,161$ & $18,71 \pm 0,902$ & 0,001 \\
$\mathrm{KK}$ & $13,76 \pm 1,179$ & $18,38 \pm 0,590$ & 0,001 \\
\hline $\mathrm{p}^{* *}$ & 0,667 & 0,091 & \\
\hline
\end{tabular}

Keterangan:

p* : Hasil uji beda menggunakan Wilcoxon test

$\mathrm{p}^{* *}$ : Hasil uji beda menggunakan Mann Whitney test

Berdasarkan tabel di atas hasil uji Wilcoxon test menunjukkan nilai $\mathrm{p}$ pada ke dua kelompok lebih kecil dari 0,05 yang berarti ada perbedaan skor indeks kesegaran jasmani yang bermakna sebelum dan sesudah perlakuan. Terjadi peningkatan kesegaran jasmani sebesar $72,79 \%$ pada Kelompok Perlakuan sebesar $74,86 \%$ pada Kelompok Kontrol.

Hasil uji Mann Whitney pada kelompok perlakuan dan kelompok kontrol menunjukkan nilai $\mathrm{p}$ lebih dari 0,05 yang berarti tidak terdapat perbedaan peningkatan skor indeks kesegaran jasmani yang bermakna sebelum dan setelah perlakuan SSAI dan penambahan senam otak pada SSAI.

\section{PEMBAHASAN}

\section{Peningkatan Memori Jangka Pendek pada Kelompok Penambahan Senam Otak pada SSAI dan Kelompok SSAI}

Berdasarkan uji Wilcoxon pada penelitian ini disimpulkan bahwa penambahan Senam Otak pada SSAI dapat meningkatkan memori jangka pendek.

Dari data penelitian di atas ditemukan bahwa SSAI memberikan pengaruh dalam meningkatkan memori jangka pendek siswa. SSAI ini termasuk latihan fisik. Latihan fisik memberikan manfaat pada proses belajar dan memori, serta melindungi sel saraf dari proses neurodegeneratif. Manfaat lain dari latihan fisik adalah membantu menurunkan depresi atau tingkat kecemasan dan stres yang biasanya muncul pada siswa ketika beban belajar semakin meningkat.

SSAI berdasarkan karakteristik gerak dapat mengaktivasi sistem muskuloskeletal secara adekuat dan seimbang dan akan memberikan pengaruh pada komponenkomponen kesegaran jasmani sehingga dapat meningkatkan kebugaran siswa. ${ }^{9}$

Peningkatan atensi siswa sangat berpengaruh dalam peningkatan memori jangka pendek. Memori jangka pendek yang meningkat oleh karena pengaruh SSAI disebabkan adanya peningkatan perhatian 
setelah pelaksanaan senam. Menurut Dennison dan Gaul (2006), efisiensi fungsi perhatian dapat meningkat karena di berikannya senam otak, dimana senam otak bisa meningkatkan dan memperbaiki fungsi penyimpanan dan pengambilan informasi. ${ }^{6}$

Penelitian terbaru mengungkapkan adanya peran asam laktat sebagai sumber energi yang dapat digunakan otak untuk melakukan fungsinya. Pada dasarnya, asam laktat adalah hasil sisa proses metabolisme karbohidrat tanpa oksigen (metabolisme anaerob). Sel-sel di otot memproduksi asam laktat ketika suplai oksigen di jaringan otot tidak mencukupi untuk produksi energi. Asam laktat memasok energi untuk mendukung fungsi kognitif otak, selama periode glukosa darah rendah seperti latihan aerobik berkepanjangan. Penemuan ini membantu menjelaskan mengapa otak dapat berfungsi dengan baik pada saat-saat ketika kebutuhan tubuh akan bahan bakar dan oksigen ada di level tinggi. Penelitian ini membuka pintu ke area baru penelitian otak yang berkaitan dengan memahami efek neurologis spesifik asam laktat. ${ }^{10}$

Penambahan senam otak pada SSAI akan mengaktifkan mekanisme integrasi otak. Peningkatan skor memori jangka pendek pada kelompok ini dapat disebabkan oleh adanya optimalisasi kerja ke dua belah hemisfer. Proses integrasi ke dua hemisfer ini terjadi lewat gerakan-gerakan pada senam otak. Gerakan-gerakan pada senam otak menjembataniterbentuknya koneksi atau hubungan antara otak dan tubuh. Otak mengontrol semua fungsi tubuh. Jika kita melakukan gerakan-gerakan untuk mengakses otak, semua area pada otak yang mempunyai hubungan dalam proses belajar dapat terintegrasi sehingga bisa menstimulasi siswa untuk memaksimalkan penggunaan ke dua belah hemisfer. ${ }^{11}$

Dalam penelitian yang dilakukan oleh Dewi (2010), ditemukan bahwa tingkat konsentrasi siswa dalam belajar mengalami peningkatan karena terstimulasinya fungsi perhatian atau atensi setelah pemberian senam otak $^{12}$, penelitian Nugroho (2016) juga mengemukakan hal yang sama, di mana anak dengan Attention Deficit Disorder (ADD) mengalami peningkatan pada atensinya. Anak dengan ADD memiliki gangguan pada tahapan sosialisasi dan belajar karena ketidakmampuannya dalam memusatkan perhatian pada keadaan atau lingkungan yang dihadapi. Setelah pemberian senam Otak, rating scale atensi pada subjek mengalami peningkatan. ${ }^{13}$

Gerakan pada senam otak dapat mengaktifkan organ dan sistem pada tubuh manusia melalui kerja sistem saraf dengan membagi gerakan-gerakan pada tiga dimensi, yaitu dimensi lateralis, dimensi pemfokusan dan dimensi pemusatan. Dimensi-dimensi tersebut berkaitan dengan fungsi otak yang spesifik dan menggambarkan penggunaan otak secara menyeluruh dalam proses belajar. Pola tiga dimensi dalam senam otak bertujuan untuk menciptakan kongruensi dimana akses putaran cepat dan putaran lambat bisa terintegrasi pada tiga dimensi ini. Karena keadaan seimbang hanya bisa tercipta bila semua tiga dimensi bekerja secara konsisten. ${ }^{14}$

\section{Peningkatan Indeks Kesegaran Jasmani pada Kelompok Penambahan Senam Otak pada SSAI dan Kelompok SSAI}

Berdasarkan uji Wilcoxon pada penelitian ini disimpulkan bahwa penambahan senam otak pada SSAI dan SSAI dapat meningkatkan indeks kesegaran jasmani.

SSAI memberikan pengaruh pada komponen-komponen kesegaran jasmani karena dengan gerakan fisik yang diberikan pada anak dapat meningkatkan pemahaman anak terhadap prinsip mekanika gerakan sehingga terbentuk gerak yang dipahami dan disadari, dan dalam proses selanjutnya keterampilan gerak bisa terlatih. SSAI pada penerapannya merupakan struktur gerak yang bervariasi, yang berdasarkan unsur geraknya mengandung gerak lokomotor, non lokomotor dan manipulatif. Dilihat berdasarkan struktur lokomotor dapat meningkatkan kekuatan, kecepatan, daya tahan, kelincahan dan keseimbangan. Berdasarkan pola gerak non lokomotor meningkatkan kelentukan dan keseimbangan statis sehingga koordinasi anak terbentuk. 
Peningkatan indeks kesegaran jasmani sebagai efek penambahan senam otak pada SSAI dikarenakan senam otak dapat memberikan stimulasi baru di otak yang bisa berdampak pada hubungan antar neuron yang menjadi kuat sehingga otak akan lebih peka terhadap informasi yang masuk dan area internal representatif pada otak akan mengalami peningkatan akibat terbentuknya jalur baru karena adanya jembatan antar neuron atau sinaps baru. Senam otak dapat menstimulasi gerakan. Gerakan yang terbentuk dapat mempengaruhi plastisitas otak. Hal tersebut berkaitan dengan penguatan sinaps yang mendukung stimulasi gerakan yang lebih baik sehingga tercipta gerakan yang lebih terkoordinasi dan keseimbangan yang lebih baik. Internal representative yang lebih luas membuat sikap tubuh menjadi lebih baik walaupun pada berbagai perubahan gerak, sehingga terciptanya keadaan ini bisa membantu perbaikan postur yang selanjutnya akan memperbaiki penampilan tubuh ketika melakukan SSAI sehingga performa anak akan meningkat. ${ }^{15}$

Peningkatan indeks kesegaran jasmani karena adanya penambahan senam otak pada SSAI karena gerakan senam otak bisa menstimulasi sensorik dan motorik sehingga kemampuan otak akan lebih baik dalam mengorganisir informasi sensoris yang masuk, baik infomasi yang berasal dari dalam tubuh maupun informasi dari lingkungan luar. $^{16}$

Peningkatan kesegaran jasmani Kelompok Perlakuan dan Kelompok Kontrol dalam penelitian ini memiliki nilai yang relatif sama. Hal ini terjadi karena unsur gerakan pada SSAI mempengaruhi sistem muskuloskeletal secara dominan sehingga lebih berpengaruh pada komponen-komponen kesegaran jasmani berupa kekuatan otot, daya tahan otot, daya ledak otot, kecepatan, kelentukan, kelincahan, ketepatan, keseimbangan, koordinasi.

Dalam penelitian Siamy et al (2015), menunjukkan bahwa senam otak membuat adanya peningkatan komponen kesegaran jasmani berupa keseimbangan dinamis secara signifikan pada anak usia 7-8 tahun dibandingkan Senam Kesegaran Jasmani. Hal ini terjadi karena adanya perbaikan tingkat saraf karena kompleksnya gerakan yang ada pada senam otak bila dibandingkan dengan gerakan pada senam SKJ 2008 sehingga hormon-hormon yang penting seperti brain derivated neurotropic factor (BDNF) pada hipocampus, frontal mid brain didapati mengalami peningkatan bila dibandingkan dengan SKJ. ${ }^{17}$

Menurut penelitian Thomas (2012), menyatakan bahwa gerakan pada senam otak sangat mempengaruhi fungsi masing-masing bagian otak. Gerakan yang ada dapat mengaktivasi otak sehingga membuat otak memberi respons terhadap perubahan keadaan gerakan tubuh terhadap lingkungan. ${ }^{18}$

Menurut penelitian berikutnya oleh Hafez (2017), menyatakan bahwa senam otak yang diberikan selama 8 minggu memberikan hasil berupa peningkatan pada tes standing stork, tes keseimbangan dinamis dan meningkatkan level manipulating skills pada atlet pemula gimnastik, di mana senam otak meningkatkan dan memperbaiki unsur-unsur berupa keseimbangan, ketenangan, gerakan-gerakan tubuh, koordinasi, ritme dan rasa kinestetik yang membutuhkan kerja sama dari seluruh persendian tubuh khususnya proprioseptif. ${ }^{19}$

Menurut Church (2018) dalam ulasannya tentang Brain Gym for People in Sport mengatakan bahwa senam otak dalam olahraga tujuannya adalah untuk memaksimalkan koordinasi pikiran dan tubuh melalui integrasi refleks yang dapat meningkatkan kinerja secara optimal untuk setiap individu bahkan tim dalam olahraga apapun. ${ }^{20}$

Berkembangnya koordinasi ditandai dengan perkembangan spatial awareness, sehingga individu bisa memperkirakan jarak melalui proses persepsi. Dalam proses mempersepsikan sesuatu, dibutuhkan pengamatan dan proses penalaran yang baik terhadap lingkungan yang ada di sekitar sehingga individu bisa menginterpretasikan dan memberi makna terhadap stimulus yang ada melalui kerja sistem pengindraan. Proses ini berlangsung di otak. ${ }^{21}$

Gerakan pada SSAI bisa membantu pemahaman anak terhadap prinsip mekanika gerak sehingga proses gerak yang dipahami 
dan disadari membantu proses terciptanya keterampilan gerakan. Kemampuan anak dalam bergerak dapat terstimulasi dengan pemberian senam sehingga tercipta perkembangan dalam keterampilan gerak tertentu, karena keterampilan gerak bukan hanya dipengaruhi oleh kematangan anak dalam bergerak, tetapi juga dipengaruhi oleh faktor proses belajar gerak. ${ }^{22}$

Unsur gerakan dalam SSAI dan senam otak meningkatkan aktivitas fisik sehingga komponen motorik seperti kelincahan, keseimbangan dan koordinasi pada anak bisa optimal. Unsur dalam gerakan SSAI dapat mempengaruhi sistem muskuloskeletal dan proprioseptif secara dominan, sedangkan senam otak akan lebih meningkatkan input proprioseptive dengan mengaktivasi sistem neuromuskuler dengan re-edukasi postur melalui gerakan yang kompleks. ${ }^{6}$

Senam otak dapat memberikan pengaruh pada beberapa unsur-unsur kesegaran jasmani, di antaranya keseimbangan, koordinasi, daya tahan, kelentukan, kelincahan, ketepatan karena gerakan pada senam otak bisa menstimulasi beberapa bagian otak. Proses stimulasi dengan gerakan senam otak membuat otak lebih cepat teraktivasi sehingga bisa memberi rekasi yang cepat terhadap keadaan yang membutuhkan keseimbangan ataupun koordinasi yang lebih baik, akan tetapi senam otak tidak spesifik memberikan pengaruh secara langsung pada beberapa unsur kesegaran jasmani seperti kekuatan, daya tahan kardiovaskuler, daya ledak otot sehingga nilai kesegaran jasmani sebelum dan sesudah perlakuan pada kedua kelompok mempunyai nilai yang relatif sama. $^{23}$

\section{Keterbatasan Penelitian}

Keterbatasan penelitian terdapat pada nilai memori jangka pendek dan sebelum penelitian yang tidak diklasifikasi berdasarkan norma nilai untuk membedakan nilai yang masuk klasifikasi rendah dan tinggi. Begitu juga dengan nilai kesegaran jasmani sebelum penelitian yang tidak diklasifikasi berdasarkan norma nilai untuk membedakan nilai yang masuk klasifikasi kesegaran jasmani kurang dan baik.

\section{SIMPULAN}

1. SSAI dapat meningkatkan memori jangka pendek

2. SSAI dapat meningkatkan kesegaran jasmani

3. Penambahan senam otak pada SSAI dapat meningkatkan memori jangka pendek

4. Penambahan senam otak pada SSAI dapat meningkatkan kesegaran jasmani

5. Penambahan senam otak pada SSAI lebih meningkatkan memori jangka pendek daripada SSAI.

6. Penambahan Senam Otak pada SSAI tidak berbeda dalam meningkatkan kesegaran jasmani bila dibandingkan dengan pemberian SSAI

\section{SARAN}

1. Melakukan klasifikasi pada siswa berdasarkan norma nilai memori jangka pendek dan kesegaran jasmani untuk membedakan nilai yang masuk klasifikasi rendah dan tinggi untuk memori jangka pendek dan yang masuk klasifikasi kesegaran jasmani kurang dan baik.

2. Melakukan kontrol terhadap variabel pengganggu seperti status gizi dan jam waktu tidur sebelum pelaksanaan tes dari subjek penelitian.

3. Penambahan senam otak pada SSAI terbukti dapat meningkatkan memori jangka pendek siswa SD Inpres Pondang, maka penulis menyarankan untuk dapat menambahkan senam otak pada program senam kesegaran jasmani yang ada di Sekolah Dasar.

\section{DAFTAR PUSTAKA}

1. Surna, I., Pandeirot, O.D. 2014. Psikologi Pendidikan 1. Jakarta: Erlangga. Hal.5455

2. Kumaran, D. 2008. Short-Term Memory and the Human Hippocampus. The Journal of Neuroscience. Vol.28, No.15: 3837-3838

3. Yuliawan, D,. 2015. Peningkatan Kebugaran Jasmani Melalui Permainan untuk Anak SD (serial online), diakses tanggal 19/11/2017. Available from : 
URL:

http://bukanketerbatasan.blogspot.co.id/2 015/04/peningkatan_kebugaran_jasmani_ melalui.html

4. Dikir, Y., Badi'ah, A., Fitriana, L.B. 2016. Senam Otak (Brain Gym) Berpengaruh terhadap Tingkat Stres pada Anak Usia Sekolah Dasar Kelas V di SD N Pokoh 1 Wedomartani Ngemplak Sleman Yogyakarta. Journal Ners and Mid Wifery Indonesia. Vol.4, No.2: 70-74

5. Kamajaya, I., Dantes, N., Kanca, N.I. 2013. Pengaruh Pelatihan Senam Kesegaran Jasmani 2008 Terhadap Volume Oksigen Maksimal Ditinjau Dari Kemampuan Awal. E-Journal Program Pascasarjana Universitas Pendidikan Ganesha. Vol 3.

6. Dennison, P.E., Gaul, E.D., 2006. Brain Gym and Me. Jakarta: PT. Grasindo. Hal. 319-320

7. Marzuki. 2012. Unsur-unsur Kesegaran Jasmani. (Serial Online), diakses tanggal $17 \quad$ Mei 2018. Diakses dari:http://marzuki49.blogspot.com/2012/ 02/unsur-unsur-kesegaran-jasmani.html.

8. Pocock, S.J. 2008. Clinicsl Trials: A Practical Approach. A Wiley Medical Publication. John Wiley \& Sons. New York. p.128-129.

9. Hillman C.H., Kamijo, K., Scudder, M. 2011. Review of Chronic And Acute Physical Activity Participation on Neuroelectric Measures of Brain Health And Cognition During Childhood. National Institutes of Health. Vol.52 (Suppl.1): S21-S28.

10. Todd, J.J., 2014. Lactate: Valuable For Physical Performance and Maintenance of Brain Function During Ecxercise. Bioscience Horizons: The International Journal of Student Research, Oxford Academic. Vol. 7: 1-7.

11. Nielsen, J.A., Zielinski, B.A., Ferguson, M.A., Lainhart, J.E., Anderson, J.S. 2013. An Evaluation of The Left-Brain Vs Right Brain Hypothesis With Resting State Functional Connectivity Magnetic Resonance Imaging. PLoS ONE Journal. Vol. 8, No.8: 71275.
12. Dewi, P.N. 2010. Pengaruh Senam Otak (Brain Gym) terhadap Peningkatan Konsentrasi Belajar Siswa (Umur 11-12 tahun) di SDN Nambanjan Kidul $05 \mathrm{Kec}$. Jiwan Kab. Madiun. Majalah Kesehatan FKUB.

13. Nugroho, Y. 2016. "Efek Brain Gym dalam Mningkatkan Perhatian Anak Attention Deficit Disorder (ADD)" (skripsi). Surakarta: Universitas Setia Budi.

14. Dennison, P.E., Gaul, E.D. 2004. Brain Gym Senam Otak Buku Panduan Lengkap. Jakarta: PT. Grasindo.

15. Cramer, S.C., Sur, M., Dobkin, B.H., O’Brien, C., Sanger, T.D. 2011. Harnessing Neuroplasticity For Clinical Applications. Brain Journal of Neurology. Vol. 134: 1591-1609

16. Watson, M.A., Black, F.O. 2008. The Human Balance System-A Comples Coordination of Central And Peripheral Systems. Vestibular Disorders Association. Available from: http://www.vestibular.org/

17. Siamy, H.A., Pangkahila, J.A., Irfan, M. 2015. Senam Otak Lebih Meningkatkan Keseimbangan Dinamis Daripada SKJ 2008 Pada Anak Usia 7-8 Tahun Di Kecamatan Simpang Teritip Bangka Barat. Sport and Fitness Journal. Vol.3, No.3: 26-37.

18. Thomas, M. 2012. The Effect of Different Movement Exercise On Cognitive And Motor Abilities. Advances in Physical Education. Vol.2, No.4: 172178.

19. Hafez, R. 2017. Effect of Brain Gym On Manipulating Skills and Balance for Begginers in Rhytmic Gymnastics. Science, Movement and Health Journal. Vol.17, No.1: 66-72.

20. Church, M. 2018. Brain Gym for People in Sport. (serial online). Available from: URL:http:/www.braindevelopmentmalta. com/brain-gym/sport/

21. Kalinggajati,P,H. 2013. "Pengaruh Senam Kesegaran Jasmani (SKJ)Terhadap Koordinasi Mata dan Kaki pada Anak Usia 8-9 Tahun" (skripsi). Surakarta: Poltekes Surakarta. 
22. Steward, O. 2012. Functional

Neuroscience. USA. First Edition.

23. Wahyuni, N., Dinata, I.M.K., Juhanna, I.V., Nugraha, M.H.S. 2017. Comparing The Effects of Brain Exercise to Listening to Mozart in Improving Short Term Memory. Indonesian Journal of Biomedical Science. Vol.11, No.2: 20-24 